\title{
Invasion of fish epithelial cells by Photobacterium damselae subsp. piscicida: evidence for receptor specificity, and effect of capsule and serum
}

\author{
M. Victoria López-Dóriga, Andrew C. Barnes, Nuno M. S. dos Santos \\ and Anthony E. Ellis
}

FRS Marine Laboratory, PO Box 101, Victoria Road, Aberdeen AB11 9DB, UK
Author for correspondence: M. Victoria López-Dóriga. Tel: +44 1224 295612. Fax: +44 1224295620. e-mail: doriga@marlab.ac.uk

Photobacterium damselae subsp. piscicida is a fish pathogen which causes serious disease in commercial warmwater fish species. Because information on the initial stages of the infection is scarce, an investigation of the invasion ability of this pathogen was undertaken utilizing a fish epithelial cell line (epithelioma papillosum carpio, EPC), a virulent capsulated strain of $P$. damselae (MT1415), an avirulent non-capsulated strain of $P$. damselae (EPOY8803-II) and Escherichia coli HB101 as a non-invasive control. P. damselae was found to be able to adhere to and invade fish epithelial cells and remain inside them for 6-9 $\mathrm{h}$. There were no significant differences in invasiveness between the capsulated and non-capsulated strains. A kinetics study demonstrated that $P$. damselae invasiveness was more efficient at low m.o.i., reaching saturation at higher m.o.i., suggesting internalization may be receptor-mediated. Invasion efficiency (IE) was significantly higher than in the control $E$. coli HB101. Engulfment of bacteria was possibly by an endocytic process and was unaffected by killing the bacteria with UV light. However, heat-killed bacteria had significantly reduced invasion capability. Ultrastructural studies showed that inside the epithelial cells, the bacteria remained within large vacuoles for a few hours and no evidence of intracellular replication was found, by either fluorescence or electron microscopic studies. Normal sea bass serum slightly reduced the invasion capability of the MT1415 strain, but heat-inactivated normal serum had no effect. On the other hand, heat-inactivated fish antiserum raised against the same strain reduced the percentage of invaded epithelial cells by $50 \%$. As for other pathogens, an intracellular phase of $P$. damselae may be a mechanism to delay or avoid phagocytosis and host immune responses, favouring the spread of infection.

Keywords: Photobacterium damselae subsp. piscicida, fish epithelial cells, invasion efficiency

\section{INTRODUCTION}

Pasteurellosis is a serious bacterial disease caused by Photobacterium damselae subsp. piscicida (previously Pasteurella piscicida) which affects commercially important warmwater fish species, such as sea bass, white bass, yellowtail, striped bass and gilthead seabream (Thune et al., 1993). The pathology of pasteurellosis has

Abbreviations: EPC, epithelioma papillosum carpio; IE, invasion efficiency. been widely reported (Kubota et al., 1970; Wolke, 1975; Hawke et al., 1987; Toranzo et al., 1991; Noya et al., 1995b), and acute and chronic infections have been described.

The pathogenesis of $P$. damselae is poorly understood. It has been demonstrated that the polysaccharide capsular layer has an important role in the virulence of the pathogen (Magariños et al., 1996b), as also have the extracellular products and iron availability (Magariños et al., 1992, 1994). Regarding the interaction of $P$. 
damselae with phagocytes, the results have been contradictory. Whilst morphologically intact bacteria within macrophages have been found in vivo (Kubota et al., 1970; Nelson et al., 1981; Kusuda \& Salati, 1993; Noya et al., 1995a, b), suggesting that $P$. damselae can survive inside macrophages, in vitro studies (Skarmeta et al., 1995; Arijo et al., 1998) have indicated that macrophages from three different fish species were able to kill the bacteria. More recently, Barnes et al. (1999) have confirmed that this species is unable to respond to oxidative attack such as that experienced during the macrophage respiratory burst. On the other hand, it has been suggested that $P$. damselae could avoid host defence mechanisms and antimicrobial agents by intracellular survival in non-phagocytic cells (Magariños et al., 1996a) since it has been demonstrated that this bacterium is capable of invading different fish cell lines (Magariños et al., 1996a; Yoshida et al., 1997).

The ability to invade epithelial cells is a key determinant of virulence for several human pathogenic bacteria such as Escherichia coli and Yersinia, Salmonella and Shigella species (Galán, 1994; Zierler \& Galán, 1995). Amongst fish pathogens, this capacity has been demonstrated for Aeromonas hydrophila (Leung et al., 1996; Tan et al., 1998) and Vibrio anguillarum (Wang et al., 1998). P. damselae is considered weakly or moderately adherent and invasive to various fish cell lines (Romalde \& Magariños, 1997). Moreover, it showed a high binding capacity to fish intestines (Magariños et al., 1996a). The adherence seemed to be mediated by a protein or glycoprotein receptor of the bacterial cell surface, and the internalization of the bacteria was an actin-microfilament-dependent mechanism (Magariños et al., 1996a). Although these authors have indicated that $P$. damselae is able to remain viable inside the cells for at least $2 \mathrm{~d}$, and to spread from cell to cell, it has not been demonstrated that internalization in fish cell lines is a specific process.

This study was carried out to analyse and obtain a better understanding of $P$. damselae internalization, by studying invasion efficiency (IE), the kinetics of invasion, the role of the capsule, and the effects of heating and exposure to UV light, serum and antiserum on the invasiveness of this species.

\section{METHODS}

Bacteria. A virulent capsulated strain (MT1415) and an avirulent non-capsulated strain (EPOY-8803-II) (Magariños et al., 1996b) of P. damselae subsp. piscicida were used in the present study. The capsulated strain was originally isolated from an outbreak of pasteurellosis in sea bass (Dicentrarchus labrax) in Italy and was obtained from the Marine Laboratory Collection, Aberdeen; the non-capsulated strain was isolated from red grouper (Epinephelly akaara) in Japan and was obtained from the Microbiology Department, Málaga University, Spain (Arijo et al., 1998). Strains were cultured on tryptic soy agar (TSA) supplemented with $2 \% \mathrm{NaCl}$ (TSA-2) at $22{ }^{\circ} \mathrm{C}$ for $48 \mathrm{~h}$, or in tryptone soya broth (TSB) supplemented with $2 \% \mathrm{NaCl}$ (TSB-2) overnight at $22^{\circ} \mathrm{C}$ with shaking.
Tissue culture. Epithelioma papillosum carpio (EPC) cells were grown in $75 \mathrm{~cm}^{2}$ flasks containing Glasgow modification of Eagle's minimal essential medium (G-MEM) (ICN) with $10 \%$ fetal bovine serum (FBS, Sigma). In all the experiments, EPC cells were grown to a confluence of $80-90 \%$ (between $2 \times 10^{6}$ and $1 \times 10^{7}$ cells per $25 \mathrm{~cm}^{2}$ ).

Bacterial hydrophobicity. The cell surface hydrophobicity of the $P$. damselae strains used was studied using the salt aggregation test (SAT). The assay was performed essentially as described by Lindhal et al. (1981). Briefly, serial doubling dilutions of ammonium sulphate were made ranging between $4 \mathrm{M}$ and $0.003 \mathrm{M}$ in $0.002 \mathrm{M}$ sodium phosphate buffer (pH 6.8). To $50 \mu \mathrm{l}$ of each dilution, $50 \mu \mathrm{l}$ of bacterial suspension $\left(\approx 10^{10}\right.$ c.f.u. $\mathrm{ml}^{-1}$ ) was added. The lowest concentration at which agglutination occurred was recorded for each strain.

Adherence assay. Bacteria were grown as indicated above and $25 \mu \mathrm{l}$ added to each well of a 24-well tissue culture plate containing a sterile glass coverslip seeded with EPC cells. The plates were centrifuged $(150 \mathrm{~g}, 5 \mathrm{~min})$ to achieve contact between bacteria and cells. The infected cultures were incubated at $22{ }^{\circ} \mathrm{C}$ from $15 \mathrm{~min}$ to $24 \mathrm{~h}$. After incubation, coverslips were washed with PBS $(137 \mathrm{mM} \mathrm{NaCl}, 2.7 \mathrm{mM}$ $\mathrm{KCl}, 10 \mathrm{mM} \mathrm{Na}_{2} \mathrm{HPO}_{4}$ and $1.7 \mathrm{mM} \mathrm{KH}_{2} \mathrm{PO}_{4}, \mathrm{pH} 7.2$ ) to remove non-adherent bacteria, fixed with methanol, stained with Giemsa and mounted with $90 \%$ glycerol in PBS.

Quantitative invasive assay. Invasiveness of $P$. damselae MT1415 was tested and E. coli HB101 (Sigma) a non-invasive strain, was used as a negative control. From an overnight TSB culture, E. coli was inoculated into TSB and grown at $37^{\circ} \mathrm{C}$ for $3 \mathrm{~h}$ to obtain an exponential-phase culture.

EPC cells were seeded in $75 \mathrm{~cm}^{2}$ flasks and grown until $80-90 \%$ confluent. New medium was added to the cells, which were then suspended using a scraper. Cells were counted in a counting chamber and distributed in microtubes $\left(1 \times 10^{5}\right.$ EPC cells per tube) containing $1 \mathrm{ml}$ of G-MEM supplemented with $10 \%$ FBS. Serial dilutions of freshly grown, exponentialphase bacteria suspended in PBS were prepared so as to produce m.o.i.s ranging from $0 \cdot 1$ to $10^{6}$ bacteria per epithelial cell. One hundred microlitres of the bacterial suspensions was added to each tube. Each dilution was prepared in duplicate. After adding the bacteria, the microtubes were centrifuged for $5 \mathrm{~min}$ at $150 \mathrm{~g}$ to initiate contact between bacteria and epithelial cells. The infected EPC cells were incubated for $2 \mathrm{~h}$, centrifuged and resuspended for $1 \mathrm{~h}$ in $1 \mathrm{ml}$ medium containing $100 \mu \mathrm{g}$ gentamicin (Gibco) $\mathrm{ml}^{-1}$ to kill extracellular bacteria. The infected cells were washed with medium and then lysed with $1 \mathrm{ml} 1 \%$ Triton X-100 for $10 \mathrm{~min}$. One hundred microlitres of this suspension was serially diluted in PBS and the bacteria were quantified by viable count after growth for $48 \mathrm{~h}$ at $22^{\circ} \mathrm{C}$ on TSA-2 for $P$. damselae and $24 \mathrm{~h}$ at $37^{\circ} \mathrm{C}$ on TSA for E. coli.

To confirm that the conditions used in the antibiotic assay described were sufficient to eliminate the extracellular bacteria, the bactericidal activity of gentamicyn was determined essentially as described by Barnes et al. (1991), with the following modifications. A single antibiotic concentration $\left(100 \mu \mathrm{g} \mathrm{ml}^{-1}\right)$ was used in G-MEM. Inocula were prepared by serial tenfold dilution from a stock suspension of $10^{11}$ bacteria $\mathrm{ml}^{-1}$ of $P$. damselae MT1415 to give similar concentrations to those employed in the antibiotic protection assay, ranging from $5 \times 10^{10}$ to $5 \times 10^{4}$ bacteria $\mathrm{ml}^{-1}$. The suspensions and antibiotic were incubated for $1 \mathrm{~h}$ at room temperature. Following incubation, residual antibiotic was diluted out in 
fresh TSB-2 prior to determining bacterial viability by plating onto TSA-2.

Study of invasion of EPC cells by $P$. damselae using fluorescence microscopy. The technique described by Devrets \& Campbell (1991) and Bandín et al. (1995) was used to differentiate adherent from intracellular bacteria. Bacteria were harvested, washed $\left(2000 \mathrm{~g}\right.$ at $4{ }^{\circ} \mathrm{C}$ for $\left.15 \mathrm{~min}\right)$, resuspended in PBS and the $\mathrm{OD}_{540}$ adjusted to $1 \cdot 5-2 \cdot 0$. The bacteria were then labelled by incubation with $0.1 \mathrm{mg}$ FITC (isomer I, Sigma) $\mathrm{ml}^{-1}, 0 \cdot 1 \mathrm{M} \mathrm{NaHCO}_{3}, \mathrm{pH} 9 \cdot 0$ at $22^{\circ} \mathrm{C}$ for $60 \mathrm{~min}$. Bacteria were pelleted at $1500 \mathrm{~g}$ for $5 \mathrm{~min}$ and washed free of unbound FITC with PBS (5-10 times). After washing, the bacterial concentration was determined in a counting

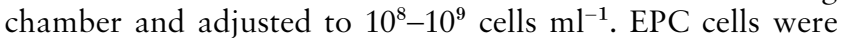
seeded in $25 \mathrm{~cm}^{2}$ flasks and incubated at $22{ }^{\circ} \mathrm{C}$ until $80-90 \%$ confluent. Prior to infection, the cells were scraped from the flasks and distributed equally into tubes ( $1 \mathrm{ml}$ per tube); $25 \mu \mathrm{l}$ labelled bacteria was then added to each tube. After centrifugation ( $150 \mathrm{~g}$ for $5 \mathrm{~min}$ ) and gentle resuspension, the infected EPC cells were incubated at $22^{\circ} \mathrm{C}$ in a rotary mixer $(20$ r.p.m.) for various times. At the end of the incubation period, the infected cells were washed three times with PBS $(150 \boldsymbol{g}$ for $5 \mathrm{~min}, 4{ }^{\circ} \mathrm{C}$ ) to remove free bacteria, centrifuged and resuspended in $100 \mu \mathrm{l}$ PBS. Ethidium bromide (Sigma) was then added $\left(500 \mu \mathrm{g} \mathrm{ml}{ }^{-1}\right.$, final concentration), and after mixing, a $10 \mu \mathrm{l}$ drop was placed on a glass slide and overlaid with a coverslip.

Preparations were observed with a fluorescence microscope (Leica DM LB). Intracellular bacteria fluoresced green and extracellular bacteria fluoresced orange. The percentage of EPC cells with at least one intracellular bacterium was calculated as the mean of random counts of 100 cells, repeated at least three times. All the assays were carried out in triplicate.

Heat and UV light treatment. To investigate if invasiveness depended on the viability of $P$. damselae and/or a heat-labile receptor, bacteria were killed by either heat or UV light. Bacteria grown for $24 \mathrm{~h}$ on a TSA-2 plate were treated with UV light for $2 \mathrm{~h}$. For heat treatment, the bacteria were suspended in PBS and heated at $80^{\circ} \mathrm{C}$ for $10 \mathrm{~min}$. Three plates of TSA-2 for each treatment were inoculated to confirm the non-viability of the bacteria. After inactivation, bacteria were labelled with FITC and incubated with EPC cells (m.o.i. $\approx 25$ ) as indicated above.

Production of sea bass anti-P. damselae antiserum. Sea bass, $1-2 \mathrm{~kg}$, were kept in seawater aquaria at $20^{\circ} \mathrm{C}$. Fish were immunized with a formalin-inactivated bacterin made from a $48 \mathrm{~h}$ culture of $P$. damselae MT1415 grown in TSB-2 at $22^{\circ} \mathrm{C}$. The bacterin was emulsified $1: 1$ in Freund's complete adjuvant. Fish were intramuscularly injected $(100 \mu \mathrm{l})$, followed by an identical immunization $30 \mathrm{~d}$ after initial injection. Sera were collected $14 \mathrm{~d}$ after the second immunization and stored at $-20{ }^{\circ} \mathrm{C}$ until required. Normal serum was collected from non-immunized fish. The agglutinating titres were determined as described by Roberson (1990). The titre of the antiserum against strain MT1415 was 1:16. No agglutination was detected after incubation of MT1415 with normal serum.

Treatment with normal serum and antiserum. Heat-inactivation of the sera was carried out at $45^{\circ} \mathrm{C}$ for $15 \mathrm{~min}$ in order to inactivate complement (Sakai, 1981).

Invasion assays were conducted as described above. After FITC-labelling and washing, the bacteria were suspended in PBS to about $3 \times 10^{8} \mathrm{ml}^{-1}$. Aliquots $(100 \mu \mathrm{l})$ were placed into five microcentrifuge tubes (in triplicate) and incubated with $500 \mu \mathrm{PBS}$ as control, sea bass normal serum, heat-inactivated normal serum or heat-inactivated antiserum for $10 \mathrm{~min}$ at room temperature. After centrifugation $(1500 \mathrm{~g}, 5 \mathrm{~min})$, bacteria were washed and resuspended in PBS. Bacteria were added to EPC (m.o.i. $\approx 15-19)$ and incubated for $2 \mathrm{~h}$. Visualization of intracellular bacteria was carried out as above by the fluorescence method.

Transmission electron microscopy. The techniques described by Watanabe et al. (1988) for rabbit platelets and by Gutenberger et al. (1997) for trout leucocytes were used. EPC cells obtained as described above were infected with bacteria. After centrifugation $(150 \mathrm{~g}$ for $5 \mathrm{~min}$ ) and gentle resuspension, the infected EPC cells were incubated for $1-9 \mathrm{~h}$ at $22^{\circ} \mathrm{C}$ in a rotary mixer (20 r.p.m.), washed three times with PBS $(900 \mathrm{~g}$ for $5 \mathrm{~min}$ ) to remove non-attached bacteria and pelleted. The pellet was resuspended in 2\% glutaraldehyde buffered with 0.05 M PIPES (Hayat, 1986) at $\mathrm{pH} 7.2$ and fixed for $1 \mathrm{~h}$ at room temperature. After washing twice with 0.025 M PIPES and centrifugation at $230 \mathrm{~g}$ for $10 \mathrm{~min}$, two drops of $2 \%$ agarose (agarose type VII, low gelling temperature $<30^{\circ} \mathrm{C}$ ) maintained at $37^{\circ} \mathrm{C}$ were added. The cells were centrifuged at $230 \mathrm{~g}$ for $5 \mathrm{~min}$ at room temperature and then left on ice until the agarose gelled. The gel was cut into small pieces $\left(1 \mathrm{~mm}^{2}\right)$, postfixed with $1 \%$ aqueous osmium tetroxide for $1 \mathrm{~h}$, and left overnight at room temperature in $2 \%$ aqueous uranyl acetate. Dehydration in an acetone series was followed by embedding in araldite (Durcupam ACM) using propylene oxide as an intermediate solvent. Ultrathin sections $(70-80 \mathrm{~nm})$ were obtained with an LKB Ultratome III, stained on the grid with Fahmy's lead citrate (Lewis \& Knight, 1977) and examined with a Hitachi H-300 electron microscope.

Statistical analysis. All the results were analysed by applying a unifactorial ANOVA test and probabilities of $<0.05$ were considered significant. The data are presented as means \pm sD.

\section{RESULTS}

\section{Adherence}

Light microscope examination of infected EPC cells demonstrated extracellular P. damselae MT1415 in close association with the plasma membrane of the epithelial cells within 15 min of infection (data not shown).

\section{Kinetics of bacterial invasion}

The bactericidal test confirmed that the gentamicin concentration and incubation time used for the invasion assay were sufficient to kill the extracellular bacteria. Bacterial IE was calculated as: (number internalized c.f.u. at the end of the assay/starting inoculum) $\times 100$. Invasion efficiency of $P$. damselae MT1415 was tested at different m.o.i.s, from $0 \cdot 16$ to $1.6 \times 10^{6}$ bacteria per EPC cell (Fig. 1a). Maximum IE (2.77\%) was observed at an m.o.i. of 0.162 and was reduced to about $1 \%$ at m.o.i.s of 1.6 and 16.0. At higher m.o.i.s, IE values decreased gradually. The non-invasive control E. coli HB101 was tested over a similar range of m.o.i.s and the maximum IE was $0.0038 \%$ (data not shown).

When bacterial invasion ability was expressed as the total number of intracellular c.f.u. recovered from the infected EPC cells (Fig. 1b), a progressive increase was found from the lowest m.o.i., reaching a value of $\sim 1.3 \times 10^{6}$ at m.o.i. $1.6 \times 10^{4}$. Thereafter, the number 

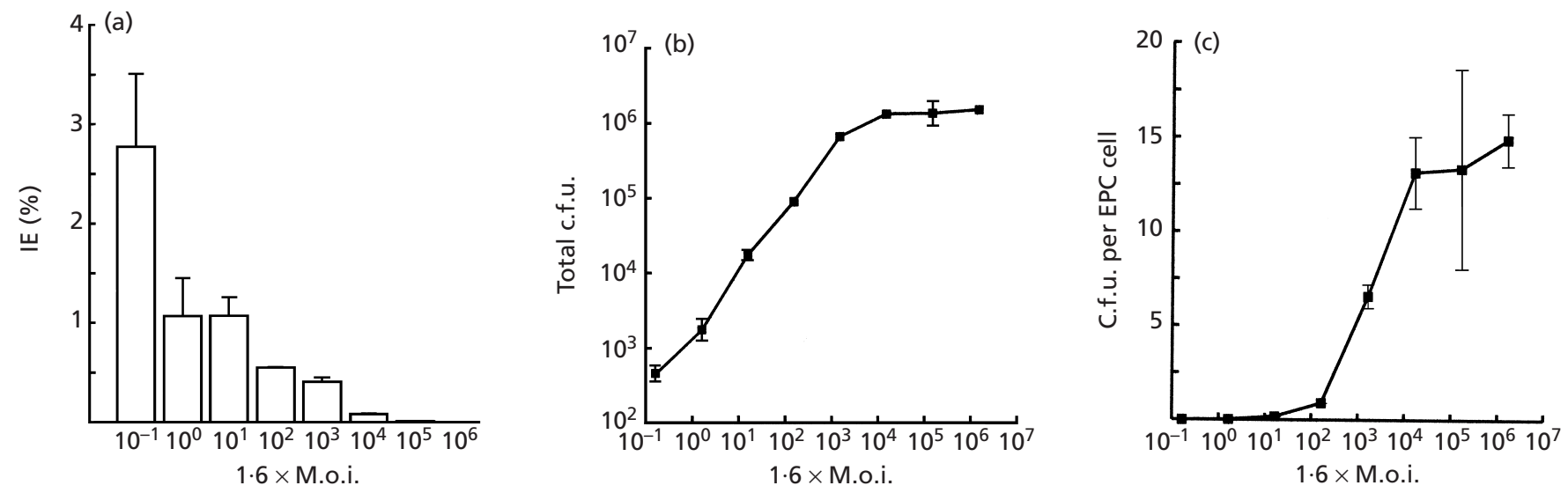

Fig. 1. Characteristics of invasion of EPC cells by $P$. damselae subsp. piscicida MT1415 after $2 \mathrm{~h}$ incubation and $1 \mathrm{~h}$ gentamicin treatment. All assays were conducted in duplicate. Results are presented as means \pm SD. (a) IE of the bacteria at different m.o.i.s. (b) Total number of bacteria internalized at different m.o.i.s. The number of internalized bacteria increased progressively and significantly $(P<0.05)$, and reached saturation at m.o.i. $1.6 \times 10^{4}$. Thereafter, there were no significant $(P>0.05)$ differences when the m.o.i. was increased. (c) Mean number of bacteria internalized per EPC cell at different m.o.i.s. As in (b), the number of bacteria per cell increased up to m.o.i. $1.6 \times 10^{4}$ and thereafter no significant increase was recorded.

increased slightly but not significantly, suggesting a limitation on entry at m.o.i.s $\geqslant 1.6 \times 10^{4}$.

The number of internalized c.f.u. per EPC cell resulting from varying the m.o.i. (Fig. 1c) increased slowly for the first four m.o.i.s and then there was a sharp increase up to 6.5 bacteria per EPC cell at m.o.i. 1620. This value doubled at m.o.i. 16000 and thereafter remained constant at m.o.i.s $\geqslant 1.6 \times 10^{4}$.

\section{Quantification of $P$. damselae internalization by the fluorescence method}

The fluorescence staining assays confirmed the presence of intracellular micro-organisms (Fig. 2). By using this method, it was possible to quantify the percentage of EPC cells infected over time, as well as the intensity of infection (i.e. number of bacteria per infected EPC cell) over time.

Uptake of $P$. damselae strain MT1415 by EPC cells was concentration- and time-dependent (Fig. 3a). Depending on bacterial concentration, between 33 and $63 \%$ of EPC cells had one or more internalized bacteria within $1 \mathrm{~h}$ of P. damselae inoculation. The percentage of infected EPC cells reached a plateau by $3 \mathrm{~h}$. Significant differences were always found between 1 and $3 \mathrm{~h}$ of incubation, but not between $3 \mathrm{~h}$ and longer incubation times ( 5 or $6 \mathrm{~h}$ ).

The number of intracellular bacteria per epithelial cell was studied over time. In this case, EPC cells were infected as above and incubated for 1,3 and $6 \mathrm{~h}$. Two $6 \mathrm{~h}$ incubations were carried out (6 and $6 \#)$. In $6 \#$, the cells were washed and new medium was added $3 \mathrm{~h}$ after infection in order to remove extracellular bacteria from the medium. After incubation, 100 EPC cells were randomly examined and the number of bacterial cells (1,

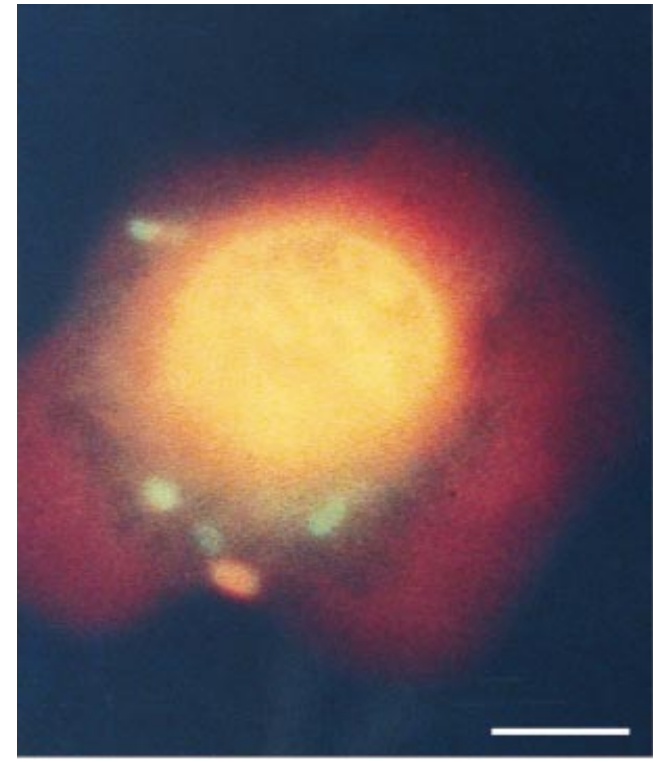

Fig. 2. EPC cell infected by $P$. damselae MT1415 as observed by fluorescence staining. Green bacteria, intracellular; orange bacteria, extracellular. Bar, $100 \mu \mathrm{m}$.

$2,3,4,5,6$ or more) in each of the infected cells was counted (Fig. 3b). The number of intracellular bacteria per EPC cell was time-dependent. After $1 \mathrm{~h}$ incubation, $44 \%$ of infected EPC cells had only 1 intracellular bacterium and $9 \%$ had six or more. After 6 h, $17 \%$ had one intracellular bacterium and $41 \%$ had six or more. The number of EPC cells with one bacterium was significantly $(P<0.05)$ reduced from 1 to 3 and $6 \mathrm{~h}$, whereas the number of epithelial cells with six or more 

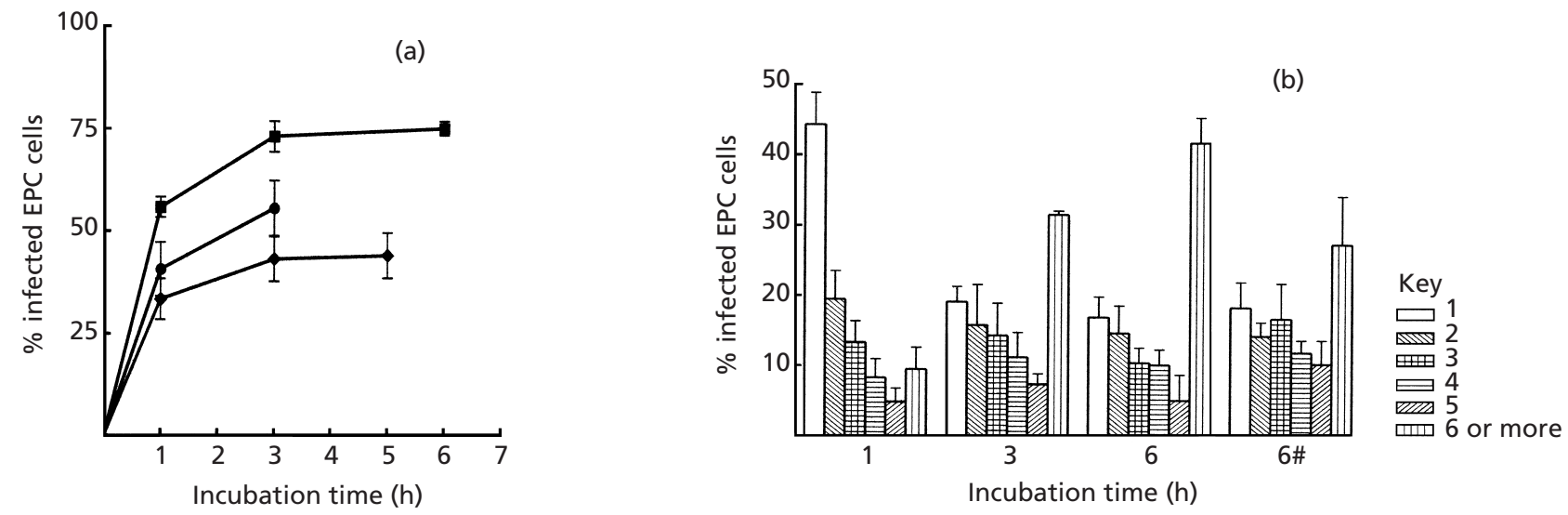

\begin{abstract}
Fig. 3. Infection of EPC cells by $P$. damselae (MT1415) over time. (a) Cells were infected with $2.28 \times 10^{8}(\diamond), 4 \cdot 64 \times 10^{8}(\bullet)$ ), or $9.92 \times 10^{8}(\square)$ bacteria (m.o.i. $\approx 5,30$ and 60 , respectively). Results are expressed as means \pm SD from three replicates for each experiment. As the bacterial concentration increased, so did the percentage of EPC cells infected. There was a significant $(P<0.05)$ increase between 1 and $3 \mathrm{~h}$ of incubation, but not between $3 \mathrm{~h}$ and longer incubation times. (b) Bars show number of intracellular bacteria per EPC cell. Time $6 \#$ represents a $6 \mathrm{~h}$ incubation period in which the bacteria were eliminated from the medium after $3 \mathrm{~h}$. Results are expressed as means \pm SD from a representative experiment carried out in quadruplicate. Bacterial concentration was $9.92 \times 10^{8}$ (m.o.i. $\left.\approx 60\right)$.
\end{abstract}

bacteria was significantly $(P<0 \cdot 05)$ increased from 1 to 3 and 6 h. However, when the bacteria were removed from the medium after $3 \mathrm{~h}$ and the cells incubated for a further $3 \mathrm{~h}(6 \#)$, there was no significant difference between the values at 3 and $6 \# \mathrm{~h}$ of incubation suggesting that the increase in the number of intracellular bacteria per EPC cell between 3 and $6 \mathrm{~h}$ resulted from uptake of further bacteria from the medium, rather than division of bacteria within the cells.

\section{Hydrophobicity and invasion of the virulent and avirulent strains}

Non-capsulated P. damselae strain EPOY-8803-II aggregated with a lower $(0.25 \mathrm{M})$ concentration of ammonium sulphate than the capsulated strain MT1415 $(>4 \mathrm{M})$. For invasion assays, EPC cells were infected with equivalent bacterial concentrations $\left(\approx 10^{8}\right.$ bacteria $\mathrm{ml}^{-1}$, m.o.i. $\approx 15$ ) of the virulent MT1415 and nonvirulent EPOY-8803-II strains, incubated for 1 and $3 \mathrm{~h}$ and observed by fluorescence microscopy. There were no significant differences between the percentage of EPC cells invaded by the two strains, either after $1 \mathrm{~h}$ (MT1415，37.8 $\pm 1 \cdot 8 \%$; EPOY-8803-II, 38.83 \pm $1 \cdot 04 \%)$ or $3 \mathrm{~h}$ (MT1415, $49 \cdot 3 \pm 5 \cdot 1 \%$; EPOY-8803-II, $49 \cdot 0 \pm 0.9 \%$ ) incubation.

\section{Effect of heat, UV light, serum and antiserum on bacterial invasiveness}

After heat and UV light treatments, no viable bacteria could be detected on TSA-2 plates, confirming complete inactivation of the bacteria. Invasiveness of heat-inactivated bacteria was greatly reduced $(9 \cdot 3 \pm 1 \cdot 5 \%$ EPC cells invaded) compared with the non-inactivated bacteria $(52 \cdot 2 \pm 4.0 \%$ EPC cells invaded). However, bacteria inactivated by UV light were still able to invade up to
$44 \cdot 8 \pm 1 \cdot 5 \%$ of EPC cells, which was not significantly $(P>0.05)$ different from the non-treated viable bacteria.

Capsulated bacteria incubated with heat-inactivated normal serum invaded a similar percentage of EPC cells $(47 \cdot 5 \pm 4 \cdot 4 \%)$ as the control (bacteria incubated with PBS) $(49 \cdot 2 \pm 2 \cdot 0 \%)$. However, when bacteria were incubated with fresh normal serum, the percentage of EPC cells infected was significantly $(P<0 \cdot 05)$, but not greatly, reduced $(36 \cdot 0 \pm 1 \cdot 5 \%)$. Incubation of the bacteria with heat-inactivated sea-bass antiserum provoked a significant $(P<0.05)$ decrease in the number of epithelial cells with intracellular bacteria $(24 \cdot 5 \pm 1 \cdot 0 \%)$.

\section{Ultrastructure of $P$. damselae infection}

Ultrastructural studies of EPC cells infected with $P$. damselae provided information on the alterations which occurred both in host cells and bacteria. EPC cells infected with bacteria were incubated for 1, 3, 5, 7 and $9 \mathrm{~h}$; non-infected EPC cells were used as control. No changes in cell morphology occurred in the control cell cultures over the experimental period (data not shown).

After $1 \mathrm{~h}$ infection, both extra- and intracellular bacteria could be seen. Extracellular bacteria were in close association with the plasma membrane (Fig. 4a). EPC cells showed cytoplasmic extensions around the bacteria which were interpreted as the first steps in the engulfment process (Fig. 4b). The intracellular bacteria were always situated within membrane-bound vacuoles (Fig. $4 \mathrm{~b}, \mathrm{c})$ and no evidence of membrane disintegration was found. Vacuoles with multiple bacteria were observed (Fig. 4c) which may have been the result of several bacteria being engulfed at the same time or of vacuole fusion. Five hours after infection, most bacteria were located within large membrane-bound vacuoles and no evidence of bacteria free in the cytoplasm was seen. 

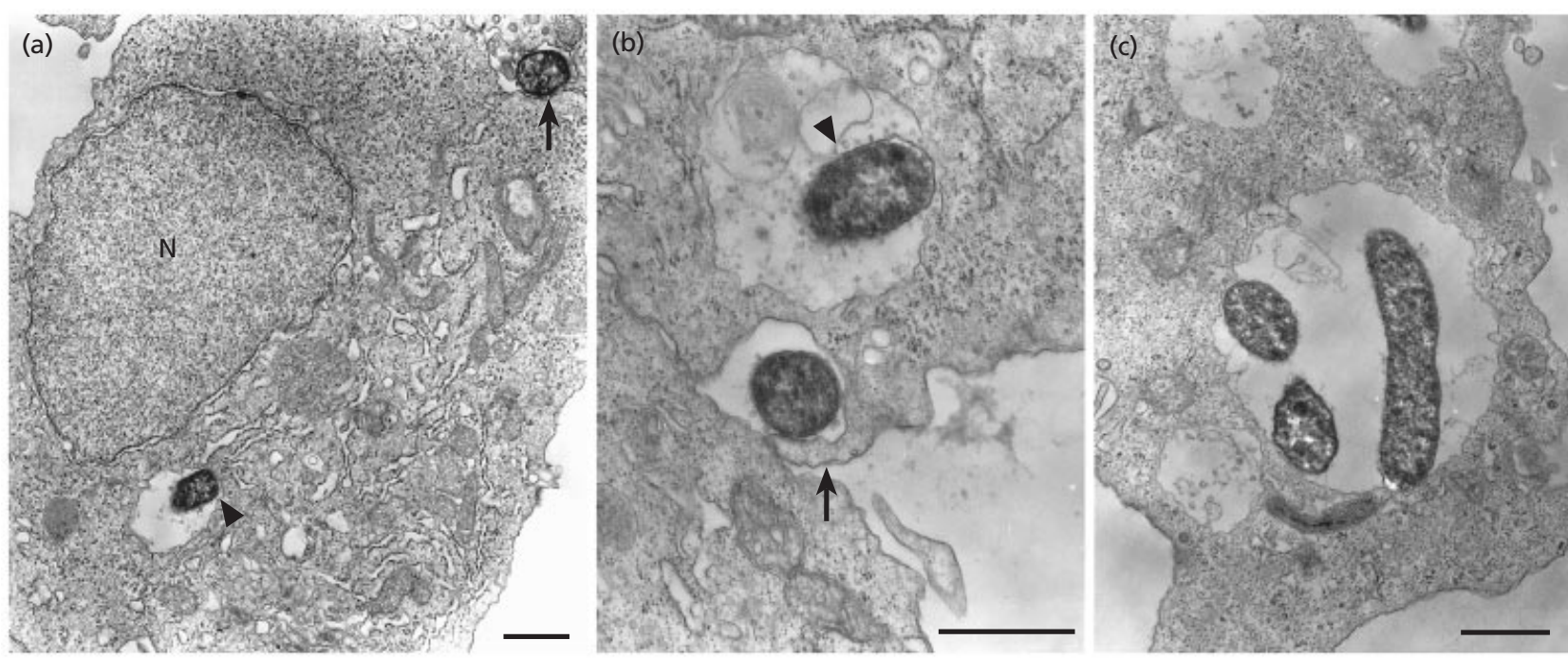

Fig. 4. Transmission electron micrographs of EPC cells infected with $P$. damselae MT1415 after 1-3 $\mathrm{h}$ incubation. (a) After $1 \mathrm{~h}$ incubation. Both extracellular (arrow) and intracellular (arrowhead) bacteria can be seen. $\mathrm{N}$, nucleus of epithelial cell. (b) After $1 \mathrm{~h}$ incubation. A cytoplasmic extension (arrow) is visible around one extracellular bacterium close to a vacuole that already contains an internalized bacterium (arrowhead). (c) After $3 \mathrm{~h}$ incubation. Once internalized, bacteria are always located inside membrane-bound vacuoles. Large vacuoles may contain two or more bacteria. Bars, $1 \mu \mathrm{m}$.
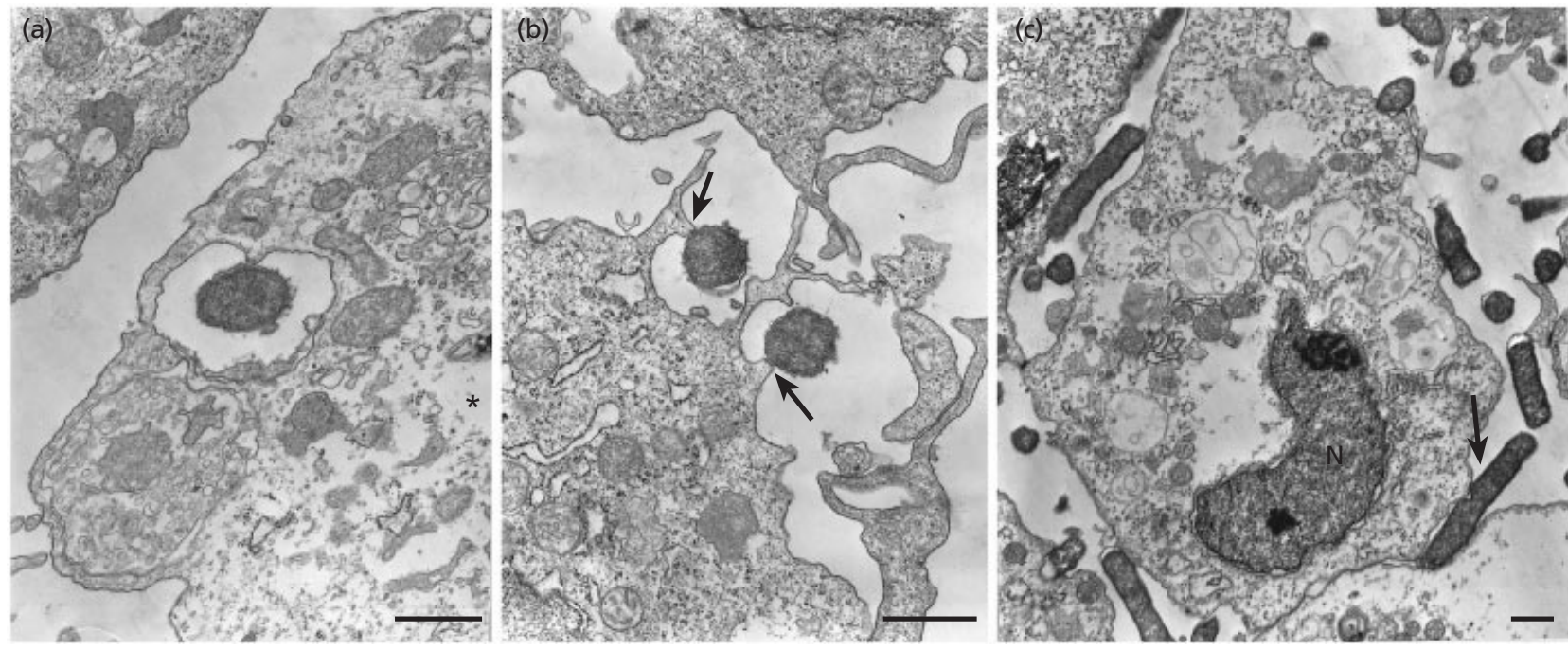

Fig. 5. Transmission electron micrographs of EPC cells infected with $P$. damselae MT1415 after 7-9 h incubation. (a) After $7 \mathrm{~h}$ incubation. Bacteria-containing vacuole close to the EPC cell surface. The cytoplasm of the EPC cell shows degenerative characteristics (asterisk). (b) After $7 \mathrm{~h}$ incubation. Exit of $P$. damselae from an EPC cell. The bacteria are still associated with the cellular membrane (arrows). (c) After $9 \mathrm{~h}$ incubation. Epithelial cells are lysed and bacteria are extracellular. Some instances of extracellular division can be seen (arrow). N, nucleus of epithelial cell. Bars, $1 \mu \mathrm{m}$

By $7 \mathrm{~h}$ post-infection, EPC cells showed degenerative changes (Fig. 5a, b). There was a decrease in the number of intracellular bacteria and the bacteria-containing vacuoles were now located closer to the EPC cell surface, separated from the medium by a thin edge of cytoplasm. Furthermore, although many extracellular bacteria were found, most of them being associated with cellular membranes, no evidence of rupture of the plasma membrane of EPC cells was observed. At $9 \mathrm{~h}$ postinfection, epithelial cells appeared to be lysed and most bacteria were extracellular. Some instances of extracellular bacterial division were observed (Fig. 5c). Despite many observations, at no time was intracellular replication or bacterial destruction observed.

\section{DISCUSSION}

P. damselae subsp. piscicida has the ability to adhere to and invade fish epithelial cells. This invasion ability has been previously demonstrated by Magariños et al. 
(1996a) and Yoshida et al. (1997). However, this is the first study of the kinetics and specificity of this process. Visual evidence of the intracellular phase of $P$. damselae inside fish epithelial cells was provided by electron microscopic observations and the light microscopic fluorescence technique. Moreover, the invasion of fish epithelial cells by $P$. damselae was confirmed by the gentamicin assays, since this antibiotic selectively kills extracellular bacteria.

Magariños et al. (1996a) indicated this species was weakly or moderately invasive. These authors tested various fish cell lines at an m.o.i. of 100 and found that up to $10^{3}$ bacteria were recovered from EPC cells after the antibiotic assay. Unfortunately, the concentration of neither the bacteria or the fish cells was stated in this report so it is not possible to compare the results directly with the present data. The invasive properties of a species depend greatly on the bacterial strain and cell lines used, as has been demonstrated for Salmonella, where the IE varied between $\approx 6$ and $38 \%$ depending on the cell lines and the bacterial strain tested (Mills \& Finlay, 1994). On the other hand, we have demonstrated that, for this species, m.o.i. has a clear effect on the number of bacteria that invade the cells. IE of $P$. damselae was maximal at the lowest m.o.i. (0.16), whereas the number of internalized bacteria and the number of bacteria per epithelial cell reached saturation at higher m.o.i.s $\left(\geqslant 1.6 \times 10^{4}\right)$. This relation between m.o.i. and invasion should be borne in mind in future studies on $P$. damselae invasiveness since the value of m.o.i. chosen represents a compromise between number of internalized bacteria and IE.

The maximum IE observed for $P$. damselae in the present study represents $2 \%$ of the initial inoculum, a percentage significantly lower than those indicated for some human invasive bacterial pathogens, such as Salmonella typhimurium (Huang et al., 1998) or Yersinia enterocolitica (Small et al., 1987), which showed IEs of $48.9 \%$ and $21 \%$, respectively. However, the level found here for $P$. damselae is higher than those reported for some other invasive species, such as Campylobacter jejuni (0.1-0.2\%) (Konkel et al., 1993), and similar to the enteroinvasive E. coli $11(2 \cdot 9 \%)$ (Small et al., 1987). The present study also showed that the induced uptake of $P$. damselae by the EPC cells was not a non-specific property of the cell line, since the cells were not invaded by the non-invasive E. coli HB101.

More intracellular organisms and higher numbers of bacteria per epithelial cell were recorded as the m.o.i. increased, until a saturation level was reached at high m.o.i.s $\left(\geqslant 1 \cdot 6 \times 10^{4}\right)$. These results suggest that internalization of $P$. damselae by EPC cells is a process mediated by receptor-ligand interactions, since this type of process is characterized by saturability (GarcíaPeñarrubia et al., 1992). Both epithelial cells and bacteria seem to be involved in the internalization process. The host cell plays an active role since the internalization of the bacteria is inhibited by cytochalasin $\mathrm{D}$ (Magariños et al., 1996a), indicating that it is dependent upon host actin microfilaments. Moreover, the ultrastructural analysis by transmission electron microscopy described here provides evidence that $P$. damselae is ingested into vacuoles, possibly by an endocytic process, in a similar way to pathogens such as Salmonella, Shigella spp. and Yersinia (Finlay \& Falkow, 1988). On the other hand, heat-killed bacteria were unable to invade the epithelial cells, whilst the UV-light-inactivated bacteria retained their invasive capabilities. This suggests that engulfment does not require $P$. damselae to be viable, but integrity of its surface components is necessary to permit interactions between the bacteria and the surface of the host cells. These results agree with those of Magariños et al. (1996a), who found that adhesive capacities are affected by heat and sugars, and suggested that adherence may be mediated by a glycoprotein of the bacterial or host cell surface.

Once internalized by non-phagocytic cells, microorganisms have different strategies to survive within the host cells. Some bacteria, such as Shigella spp. (Sansonetti et al., 1986) and Rickettsia (Heinzen et al., 1993), escape from the vacuole to multiply in the cytoplasm and later infect adjacent cells. However, there are numerous bacterial species that remain inside the vacuoles of the epithelial cells throughout infection. Species such as Salmonella and Yersinia (Finlay \& Falkow, 1988; Janda et al., 1991), Haemophilus influenzae (Virji et al., 1991) or group B streptococci (Rubens et al., 1992) are included in this group. $P$. damselae did not seem to escape from the vacuoles. At no time during infection were bacteria observed free in the cytoplasm. Instead, they were found within large cytoplasmic vacuoles where they remained viable for several hours. The intracellular time period seems to be dependent on the cell line used and assay conditions since Magariños et al. (1996a) found that $P$. damselae remained inside CHSE-214 cells for at least $2 \mathrm{~d}$, whilst in the present study the bacteria were liberated from the EPC cells 7-9 h after infection.

Some invasive bacteria replicate inside the host cells (Finlay \& Falkow, 1988). However, during the present study, examination of a large number of electron micrographs failed to show evidence of intracellular multiplication of $P$. damselae. Data from the fluorescence assay indicated an increasing number of intracellular bacteria per cell at longer incubation times, which could be due either to continuous invasion or to replication of the organisms inside the EPC cells. However, when the extracellular bacteria were eliminated from the medium there was no further increase in the number of intracellular bacteria, which supports the electron microscopic observations that $P$. damselae does not seem to replicate inside the EPC cells. Bacterial replication seemed to occur once the bacterium had left the host cell and was observed extracellularly $9 \mathrm{~h}$ after infection.

The virulence factors that contribute to IE of epithelial cells by $P$. damselae are unknown. Significant differences in IE between non-capsulated and capsulated $P$. damselae strains were not observed, although the surface hydrophobicity of the avirulent non-capsulated EPOY- 
8803-II strain is strong according to the criteria proposed by Santos et al. (1990), whilst the virulent capsulated strain MT1415 is not hydrophobic. Similar results were found by Magariños et al. (1996a) who studied the adherence to tissues of capsulated (virulent) and noncapsulated (avirulent) strains of $P$. damselae. The lack of effect of the bacterial capsule on adherence or invasion has been reported in other Gram-negative bacteria, such as H. influenzae (Lipuma \& Gilsdorf, 1987; Roberts et al., 1984) and enterotoxigenic E. coli (Guerina et al., 1983). However, studies on the role of bacterial capsules in adherence or invasion to host cells are contradictory. It has been postulated that a capsule may reduce adhesiveness in several species, such as E. coli (Runnels \& Moon, 1984), H. influenzae (St Geme \& Falkow, 1991; Virji et al., 1991), Actinobacillus pleuropneumoniae (Jacques et al., 1991) and Pasteurella multocida (Jacques et al., 1993). On the other hand, it has been found that the E. coli capsule may promote adherence (Davis et al., 1981; Chan et al., 1982). Recent studies with H. influenzae (St Geme \& Cutter, 1996) have suggested that the level of encapsulation, and not the presence of capsule by itself, influences the adhesive interactions of the organism with its host cells. In $P$. damselae, the level of encapsulation seems also to be important, since although the constitutive capsule of virulent strains does not interfere with adhesion, a thicker capsular material decreases adherence to host tissues (Magariños et al., 1996b). Since both capsulated and non-capsulated strains of $P$. damselae appear to be able to invade fish epithelial cells, the virulence of the capsulated bacteria cannot be explained solely on the basis of their ability to invade host cells.

Incubation of the bacteria prior to invasion with fresh normal sea bass serum slightly, but not significantly, reduced the percentage of EPC cells invaded by the encapsulated strain, whilst incubation with heatinactivated normal serum had no effect on invasiveness. Although this could suggest a certain degree of inhibition by the complement of fish serum on capsulated bacteria, the percentage of infected epithelial cells was still high. It has been demonstrated that bacterial capsules confer resistance to bactericidal activity of serum (Amaro et al., 1994; Daly et al., 1996), including that of $P$. damselae (Arijo et al., 1998; Magariños et al., 1996b). This slight reduction in invasiveness with fresh normal fish serum may be a consequence of some bacteria with a thinner capsule being killed by the action of complement. Incubation with heat-inactivated antiserum against strain MT1415 had a significant effect on invasion, indicating that antibodies reduce the invasiveness of the bacteria, presumably by blocking the surface receptors involved in adhesion and/or invasion. The effect of antiserum is certainly specific as heat-inactivated normal serum did not decrease invasiveness and did not agglutinate the bacteria as did the antiserum. Thus, nonspecific interactions with fish serum proteins have no effect on bacterial invasiveness.

The presence of intracellular bacteria in host cells has been interpreted as a mechanism to avoid phagocytosis and host immune responses, reducing their effectiveness and favouring the spread of infection (Virji et al., 1991; Magariños et al., 1996a; Galán, 1994; Amaro et al., 1994; Daly et al., 1996). As Virji et al. (1991) pointed out, bacteria do not need intracellular replication, only the ability to enter and survive inside the host cells and to exit. The present data show that $P$. damselae can invade fish epithelial cells, remain intracellular for a few hours, leave the host cells by lysing them and replicate extracellularly. As the capsule confers resistance to complement-dependent killing (Margariños et al., 1996b; Arijo et al., 1998), the intracellular environment may be more important to escape contact with phagocytes. Although some studies have indicated that $P$. damselae survives inside macrophages (Kubota et al., 1970; Nelson et al., 1981; Kusuda \& Salati, 1993; Noya et al., 1995a, b), Skarmeta et al. (1995) and Arijo et al. (1998) found that fish macrophages have the ability to kill the bacteria, and Barnes et al. (1999) have recently confirmed that $P$. damselae does not have adaptive defences against the bactericidal activities of macrophages. Since macrophages are able to kill $P$. damselae, the invasion of epithelial host cells may avoid, or at least delay, the contact between bacteria and macrophages, so contributing to the advance of disease.

Currently, there are no commercially available vaccines showing any degree of protection against pasteurellosis (Magariños \& Romalde, 1997). Furthermore, chemotherapeutic failure is widely reported. This may partially reflect the growing body of evidence suggesting an intracellular phase to the life-cycle of this organism (Yoshida et al., 1997; Magariños et al., 1996a; Magariños \& Romalde, 1997). The present data lend further support to this contention, demonstrating that internalization is a specific process and not passive uptake by the cell line. This intracellular phase, coupled with other factors such as the capsule (Arijo et al., 1998), may aid the pathogen in avoiding the host's cellular and humoral defences. Identification of the components and mechanisms involved in this internalization process may provide alternative targets for vaccination. There is evidence for activation of the host cell's actin system and a role for glycoproteins (Magariños et al., 1996a). It may be that a type III secretion system or similar is involved. Work towards characterizing these components is continuing in our laboratory.

\section{ACKNOWLEDGEMENTS}

We thank Dr D. A. Smail for his help and assistance, and the staff from the Virology and Microbiology Section of the Marine Laboratory, Aberdeen, for technical assistance. M.V.L.-D. was the recipient of a fellowship from the Spanish Government (Subprograma de Perfeccionamiento de Doctores y Tecnólogos en el Extranjero).

\section{REFERENCES}

Amaro, C., Biosca, E. G., Fouz, B., Toranzo, A. E. \& Garay, E. (1994). Role of iron, capsule, and toxins in the pathogenicity of Vibrio vulnificus biotype 2 for mice. Infect Immun 62, 759-763. 
Arijo, S., Borrego, J. J., Zorrilla, I., Balebona, M. C. \& Moriñigo, M. A. (1998). Comparison of the immune response of gilt-head seabream (Sparus aurata L.) to capsulated and uncapsulated strains of Photobacterium damsela subsp. piscicida. Fish Shellfish Immunol 8, 63-72.

Bandín, I., Rivas, C., Santos, Y., Secombes, C. J., Barja, J. L. \& Ellis, A. E. (1995). Effect of serum factors on the survival of Renibacterium salmoninarum within rainbow trout macrophages. Dis Aquat Org 23, 221-227.

Barnes, A. C., Lewin, C. S., Hastings, T. S. \& Amyes, S. G. B. (1991). Susceptibility of the fish pathogen Aeromonas salmonicida to flumequine. Antimicrob Agents Chemother 35, 2634-2635.

Barnes, A. C., Balebona, M. C., Horne, M. T. \& Ellis, A. E. (1999). Superoxide dismutase and catalase in Photobacterium damselae subsp. piscicida and their roles in resistance to reactive oxygen species. Microbiology 145, 483-494.

Chan, R., Acres, S. D. \& Costerton, J. W. (1982). Use of specific antibody to demonstrate glycocalyx, K99 pili, and the spatial relationships of $\mathrm{K} 99+$ enterotoxigenic Escherichia coli in the ileum of colostrum-fed calves. Infect Immun 37, 1170-1180.

Daly, J. G., Kew, A. K., Moore, A. R. \& Olivier, G. (1996). The cell surface of Aeromonas salmonicida determines in vitro survival in cultured brook trout (Salvelinus fontinalis) peritoneal macrophages. Microb Pathog 21, 447-461.

Davis, C. P., Avots-Avotins, A. E. \& Fader, R. C. (1981). Evidence for a bladder cell glycolipid receptor for Escherichia coli and the effect of neuraminic acid and colominic acid on adherence. Infect Immun 34, 944-948.

Devrets, D. A. \& Campbell, P. A. (1991). Macrophage phagocytosis: use of fluorescence microscopy to distinguish between extracellular and intracellular bacteria. J Immunol Methods 142, 31-38.

Finlay, B. B. \& Falkow, S. (1988). A comparison of microbial invasion strategies of Salmonella, Shigella and Yersinia species. In Bacteria-Host Cell Interaction, pp. 227-243. Edited by M. A. Horowitz. New York: Alan R. Liss.

Galán, J. E. (1994). Interactions of bacteria with non-phagocytic cells. Curr Opin Immun 6, 590-595.

García-Peñarrubia, P., Cabrera, L., Alvarez, R. \& Galvez, J. (1992). Effector-target interactions: saturability, affinity and binding isotherms. A study of such interactions in the human NK cell-K562 tumour cell system. J Immunol Methods 155, 133-147.

Guerina, N. G., Kessler, T. W., Guerina, V. J., Neutra, M. R., Clegg, H. W., Langermann, S., Scannapieco, F. A. \& Goldmann, D. A. (1983). The role of pili and capsule in the pathogenesis of neonatal infection with Escherichia coli K1. J Infect Dis 148, 395-405.

Gutenberger, S. K., Duimstra, J. R., Rohovec, J. S. \& Fryer, J. L. (1997). Intracellular survival of Renibacterium salmoninarum in trout mononuclear phagocytes. Dis Aquat Org 28, 93-106.

Hawke, J. P., Plakas, S. M., Minton, R. V., McPhearson, R. M., Snider, T. G. \& Guarino, A. M. (1987). Fish pasteurellosis of cultured striped bass (Morone saxatilis) in coastal Alabama. Aquaculture 65, 193-204.

Hayat, M. A. (1986). Basic Techniques for Transmission Electron Microscopy. Orlando: Academic Press.

Heinzen, R. A., Hayes, S. F., Peacock, M. G. \& Hackstadt, T. (1993). Directional actin polymerization associated with spotted fever group Rickettsia infection of Vero cells. Infect Immun 61, 1926-1935.

Huang, X.-Z., Tall, B., Schwan, W. R. \& Kopecko, D. J. (1998). Physical limitations on Salmonella typhi entry into cultured human intestinal epithelial cells. Infect Immun 66, 2928-2937.
Jacques, M., Bélanger, M., Roy, G. \& Foiry, B. (1991). Adherence of Actinobacillus pleuropneumoniae to porcine tracheal epithelial cells and frozen lung sections. Vet Microbiol 27, 133-143.

Jacques, M., Kobisch, M., Bélanger, M. \& Dugal, F. (1993). Virulence of capsulated and noncapsulated isolates of Pasteurella multocida and their adherence to porcine respiratory tract cells and mucus. Infect Immun 61, 4785-4792.

Janda, J. M., Abbott, S. L. \& Oshiro, L. S. (1991). Penetration and replication of Edwardsiella spp. in Hep-2 cells. Infect Immun 59, 154-161.

Konkel, M. E., Mead, D. J. \& Cieplak, W., Jr (1993). Kinetic and antigenic characterization of altered protein synthesis by Campylobacter jejuni during cultivation with human epithelial cells. J Infect Dis 168, 948-954.

Kubota, S., Kimura, M. \& Egusa, S. (1970). Studies on bacterial tuberculoidosis of the yellowtail. I. Symptomatology and histopathology. Fish Pathol 4, 111-118.

Kusuda, R. \& Salati, F. (1993). Major bacterial diseases affecting mariculture in Japan. Annu Rev Fish Dis 3, 69-85.

Leung, K. Y., Lim, T. M., Lam, T. J. \& Sin, Y. M. (1996). Morphological changes in carp epithelial cells infected with Aeromonas hydrophila. J Fish Dis 19, 167-174.

Lewis, P. R. \& Knight, D. P. (1977). Staining methods for sectioned material. In Practical Methods in Electron Microscopy, vol. 5, pp. 1-311. Edited by A. M. Glauert. Amsterdam: Elsevier.

Lindhal, M., Faris, A., Wadstrom, T. \& Hjerten, S. (1981). A new test based on "salting out" to measure relative surface hydrophobicity of bacterial cells. Biochim Biophys Acta 677, 471-476.

Lipuma, J. L. \& Gilsdorf, J. R. (1987). Role of capsule in adherence of Haemophilus influenzae type b to human buccal epithelial cells. Infect Immun 55, 2308-2310.

Magariños, B. \& Romalde, J. L. (1997). Immunization with bacterial antigens: Pasteurellosis. In Fish Vaccinology, pp. 167-177. Edited by R. Gudding, A. Lillehaug, P. J. Midtlying \& F. Brown. Basel: Karger.

Magariños, B., Santos, Y., Romalde, J. L., Rivas, C., Barja, J. L. \& Toranzo, A. E. (1992). Pathogenic activities of live cells and extracellular products of the fish pathogen Pasteurella piscicida. J Gen Microbiol 138, 2491-2498.

Magariños, B., Romalde, J. L., Lemos, M. L., Barja, J. L. \& Toranzo, A. E. (1994). Iron uptake by Pasteurella piscicida and its role in pathogenicity for fish. Appl Environ Microbiol 60, 2990-2998.

Magariños, B., Romalde, J. L., Noya, M., Barja, J. L. \& Toranzo, A. E. (1996a). Adherence and invasive capacities of the fish pathogen Pasteurella piscicida. FEMS Microbiol Lett 138, 29-34.

Magariños, B., Bonet, R., Romalde, J. L., Martínez, M. J., Congregado, F. \& Toranzo, A. E. (1996b). Influence of the capsular layer on the virulence of Pasteurella piscicida for fish. Microb Pathog 21, 289-297.

Mills, S. D. \& Finlay, B. B. (1994). Comparison of Salmonella typhi and Salmonella typhimurium invasion, intracellular growth and localization in cultured human epithelial cells. Microb Pathog 17, 409-423.

Nelson, J. S., Kawahara, E., Kawai, K. \& Kusuda, R. (1981). Macrophage infiltration in pseudotuberculosis of yellowtail, Seriola quinqueradiata. Bull Mar Sci Fish Kochi Uni 11, 17-22.

Noya, M., Magariños, B. \& Lamas, J. (1995a). Interactions between peritoneal exudate cells (PECs) of gilthead seabream (Sparus aurata) and Pasteurella piscicida. A morphological study. Aquaculture 131, 11-21.

Noya, M., Magariños, B., Toranzo, A. E. \& Lamas, J. (1995b). 
Sequential pathology of experimental pasteurellosis in gilthead seabream Sparus aurata. A light- and electron- microscopic study. Dis Aquat Org 21, 177-186.

Roberson, B. S. (1990). Bacterial agglutination. In Techniques in Fish Immunology, pp. 81-86. Edited by J. S. Stolen, T. C. $\begin{array}{llll}\text { Fletcher, D. P. Anderson, B. S. Roberson \& W. B. van } & \text { \& }\end{array}$ Muiswinkel. Fair Aven, NJ: SOS Publications.

Roberts, M., Jacobs, R. F., Haas, J. E. \& Smith, A. L. (1984). Adherence of Haemophilus influenzae to monkey respiratory tissue in organ cultures. J Gen Microbiol 130, 1437-1447.

Romalde, J. L. \& Magariños, B. (1997). Immunization with bacterial antigens: pasteurellosis. Dev Biol Stand 90, 167-177.

Rubens, C. E., Smith, S., Hulse, M., Chi, E. Y. \& van Belle, G. (1992). Respiratory epithelial cell invasion by group B streptococci. Infect Immun 60, 5157-5163.

Runnels, P. L. \& Moon, H. W. (1984). Capsule reduces adherence of enterotoxigenic Escherichia coli to isolated intestinal epithelial cells of pigs. Infect Immun 45, 737-740.

St Geme, J. W., III \& Cutter, D. (1996). Influence of pili, fibrils, and capsule on in vitro adherence by Haemophilus influenzae type b. Mol Microbiol 21, 21-31.

St Geme, J. W., III \& Falkow, S. (1991). Loss of capsule expression by Haemophilus influenzae type b results in enhanced adherence to and invasion of human cells. Infect Immun 59, 1325-1333.

Sakai, D. K. (1981). Heat inactivation of complements and immune hemolysis reaction in rainbow trout, masu salmon, coho salmon, goldfish and tilapia. Bull Jpn Soc Sci Fish 47, 565-571.

Sansonetti, P. J., Ryter, A., Clerc, P., Maurelli, A. \& Mounier, J. (1986). Multiplication of Shigella flexneri within Hela cells: lysis of the phagocytic vacuole and plasmid-mediated contact hemolysis. Infect Immun 51, 461-469.

Santos, Y., Bandín, I., Nieto, T. P., Bruno, D. W., Ellis, A. E. \& Toranzo, A. E. (1990). Comparison of the cell surface hydrophobicity of bacterial fish pathogens by different procedures. In Pathology in Marine Science, pp. 101-115. Edited by T. C. Cheng $\&$ F. O. Perkins. New York: Academic Press.

Skarmeta, A. M., Bandín, I., Santos, Y. \& Toranzo, A. E. (1995). In vitro killing of Pasteurella piscicida by fish macrophages. Dis Aquat Org 23, 51-57.

Small, P. L. C., Isberg, R. R. \& Falkow, S. (1987). Comparison of the ability of enteroinvasive Escherichia coli, Salmonella typhimurium, Yersinia pseudotuberculosis, and Yersinia enterocolitica to enter and replicate within HEp-2 cells. Infect Immun 55, 1674-1679.

Tan, E., Low, K. W., Wong, W. S. F. \& Leung, K. Y. (1998). Internalization of Aeromonas hydrophila by fish epithelial cells can be inhibited with a tyrosine kinase inhibitor. Microbiology 144, 299-307.

Thune, R. L., Stanley, L. A. \& Cooper, R. K. (1993). Pathogenesis of Gram-negative bacterial infections in warmwater fish. Annu Rev Fish Dis 3, 37-68.

Toranzo, A. E., Barreiro, S., Casal, J. F., Figueras, A., Magariños, B. \& Barja, J. L. (1991). Pasteurellosis in cultured gilthead seabream, Sparus aurata: first report in Spain. Aquaculture 99, 1-15.

Virji, M., Kayhty, H., Ferguson, D. J. P., Alexandrescu, C. \& Moxon, E. R. (1991). Interactions of Haemophilus influenzae with cultured human endothelial cells. Microb Pathog 10, 231-245.

Wang, X. H., Oon, H. L., Ho, G. W. P., Wong, W. S. F., Lim, T. M. \& Leung, K. Y. (1998). Internalization and cytotoxicity are important virulence mechanisms in vibrio-fish epithelial cell interactions. Microbiology 144, 2987-3002.

Watanabe, S., Sasaki, J., Wanda, T., Tanaka, Y. \& Otsuka, N. (1988). Low gel temperature agarose encapsulation of small specimens for electron microscopy. J Electron Microsc 37, 89-91.

Wolke, R. E. (1975). Pathology of bacterial and fungal diseases affecting fish. In The Pathology of Fishes, pp. 33-116. Edited by W. E. Ribelin \& G. Migaki. Madison, WI: University of Wisconsin Press.

Yoshida, T., Inglis, V., Misawa, N., Kruger, R. \& Sakai, M. (1997). In vitro adhesion of Pasteurella piscicida to cultured fish cells. J Fish Dis 20, 77-80.

Zierler, M. K. \& Galán, J. E. (1995). Paradigms in bacterial entry into host cells. In Virulence Mechanisms of Bacterial Pathogens, 2nd edn, pp. 21-31. Edited by J. A. Roth, C. A. Bolin, K. A. Brogden, F. C. Minion \& M. J. Wannemuehler. Washington, DC: American Society for Microbiology.

Received 6 July 1999; revised 6 September 1999; accepted 17 September 1999. 